\title{
Apparent Digestibility Coefficient of Proteic and Energetic Ingredients for Goldfish
}

\section{Coeficientes de Digestibilidade Aparente de Ingredientes Proteicos e Energéticos para o Kinguio}

\author{
Daniel de Magalhães Araujo*a; Ademir Calvo Fernandes Júnior; Fernando Kojima Nakagome ${ }^{\mathrm{b}}$; André Moreira \\ Bordinhon $^{\mathrm{c}}$; Margarida Maria Barros ${ }^{\mathrm{b}}$; Luiz Edivaldo Pezzato ${ }^{\mathrm{b}}$
}

\begin{abstract}
${ }^{a}$ Federal Institute of Alagoas, Environmental Technology Postgraduate Program. AL, Brazil.
'São Paulo State University, Faculty of Veterinary Medicine and Animal Science. SP, Brazil.

${ }^{c}$ Federal University of Amazonas. AM, Brazil.

*E-mail: danielzootecnista@yahoo.com.br.
\end{abstract}

\begin{abstract}
Kinguios are one of the most important ornamental fish, however the studies about ingredients digestibility for this species are insufficient. The objective of this study was to determine apparent digestibility coefficients (ADC) of dry matter, gross energy and crude protein of energetic (broken rice, corn meal, and wheat bran) and proteic (soybean meal, fishmeal and poultry by-product meal) feedstuffs for goldfish (Carassius auratus). Chromium oxide III was used as an external marker. The digestibility values of dry matter and energy, in decreasing order, were higher for broken rice (97.19 and 94.55\%), corn meal (76.61 and 77.65\%) and wheat bran (45.43 and 48.83\%) in energetic ingredients; and soybean meal (72.14 and 73.54\%), poultry by-product meal (61.77 and 69.50\%) and fish meal (47.48 and 60.65\%) in proteic ingredients. Protein digestibility values were higher for soybean meal (96.11\%) and corn meal (90.77\%) and the lowest values were observed for fishmeal $(75.53 \%)$ and wheat bran $(73.06 \%)$. In general, broken rice and soybean meal nutrients were more efficiently used by fish. Although all the studied ingredients are suitable for use in diets for goldfish, wheat bran should be used with caution because of its low digestibility.
\end{abstract}

Keywords: Carassius auratus. Corn, Broken Rice. Fishmeal. Poultry Meal.

\section{Resumo}

Kinguios são uma das mais importantes espécies de peixes ornamentais criadas mundialmente, entretanto, são insuficientes os estudos com digestibilidade de ingredientes para a espécie. O objetivo com este estudo foi determinar os coeficientes de digestibilidade aparentes (CDAs) da matéria seca, proteína bruta e energia bruta de ingredientes energéticos (quirera de arroz, farinha de milho e farelo de trigo) e proteicos (farelo de soja, farinha de peixe, farinha de vísceras de aves) para kinguios (Carassius auratus). O óxido de cromo III foi usado como marcador inerte. Os CDAs da matéria seca e energia dos ingredients energéticos foram, em ordem decrescente: quirera de arroz (97,19 e 94,55\%), farinha de milho (76,61 e 77,65\%) e farelo de trigo (45.43 e 48.83\%); enquanto nos ingredientes proteicos foram: farelo de soja (72,14 e 73,54\%), farinha de vísceras de aves $(61,77$ e 69,50\%) e farinha de peixe (47,48 e 60,65\%). CDAs da proteina foram mais altos para o farelo de soja $(96,11 \%)$ e de milho $(90,77 \%)$, enquanto os menores valores foram observados para a farinha de peixe $(75,53 \%)$ e farelo de trigo (73,06\%). Em geral, os nutrientes da quirera de arroz e do farelo de soja foram aproveitados mais eficientemente pelos peixes. Ainda que todos os ingredientes estudados sejam passiveis de uso em dietas de kinguios, o farelo de trigo deve ser utilizado com precaução, em decorrência da baixa digestibilidade.

Palavras-chave: Carassius auratus. Farinha de Peixe. Farinha de Visceras de Aves. Milho. Quirera de Arroz.

\section{Introduction}

The ornamental fish pet trade is a large, biodiverse, global industry (TLUSTY et al., 2013). The expansion of this productive sector through domestic and foreign markets depend on intensification of production systems and generation of appropriate technologies (ZUANON et al., 2006). However, there are few studies on ornamental fish nutrition, especially in tropical conditions. Considering the wide variety of species bred for this purpose, the necessity of greater mobilization by researchers becomes even more evident to elucidate many questions about nutrition of such fish.

Although in the last years a diversity of commercial feed for some ornamental fish has been developed, their formulas still lack real data about nutrient digestible values and nutritional requirements, considering the number of species. In consequence, ornamental fish when are not fed with live food, generally, receive a non-specific feed developed from practical knowledge of commercial breeders or made by fish nutrition industry, based on their own knowledge without scientific validation. Besides that, some commercial diets are priced in much higher values than conventional feed used for fish in aquaculture production, being one of the factors that contributes to feeding fish in extensive mold.

Goldfish (Carassius auratus) is a modified variety from carp, Cyprinus carpio (BANDYOPADHYAY et al., 2005), and is distributed worldwide (PAULET et al. 2003). Popularly known in Brazil as kinguio or japanese fish, it it is recognized as one of the most prized ornamental freshwater fish fish by aquarists both for their variety of colors and shapes as for their sociability and rusticity. This species is one of the most studied ornamental fish and there are some commercial diets for this fish on the market, however, those feed are still 
under development (BANDYOPADHYAY et al., 2005). Diets should meet the nutritional requirements of the species and which are intended for goldfish have been poorly understood, especially considering the development stages.

Digestibility determination of ingredients for each fish species is essential for moreaccurate determination of their nutritional requirements. Little is known about the digestibility of ingredients for goldfish, even more commonly used in formulations for fish. Therefore, the aim of this research was to determine apparent digestibility coefficients (ADC) of dry matter, gross energy and crude protein of energetic (broken rice, corn meal, and wheat bran) and proteic (soybean meal, fish meal and poultry by-product meal) feedstuffs for goldfish (Carassius auratus).

\section{Material and Methods}

This study was conducted at AquaNutri, Faculty of Veterinary Medicine and Animal Science of São Paulo State University (UNESP, Botucatu, SP - Brazil). All procedures adopted for this study were approved by the ethics committee of animal experimentation under protocol $n^{\circ} 0069 / 2017$.

Initially, a basal diet was manufactured using soybean meal and fishmeal as protein-based ingredients and broken rice and bran as energetic feedstuff. Two groups of feeds were evaluated, proteic ingredients (fishmeal, poultry meal and soybean meal) and energetic ingredients (corn meal, broken rice and wheat bran), all of them were milled in order to exhibit a diameter not higher than $0.5 \mathrm{~mm}$ diameter. Subsequently, the ingredients were mixed to basal diet as the following proportions: 7:3 ratio for proteic ingredients (70\% Reference and 30\% test-ingredient); and 6:4 for energetic ingredients (60\% Reference and 40\% test-ingredient). Proportions of tested proteic and energetic ingredients were different due to the substitution of $40 \%$ of basal diet by protein ingredients resulted in unstable pellets, probably motivated by reduced percent of starch. The experimental diets were homogenized and extruded in $2.5 \mathrm{~mm}$ pellets (Table 1 ).

Table 1 - Experimental basal and test diets

\begin{tabular}{|l|c|c|c|}
\hline \multicolumn{1}{|c|}{} & \multicolumn{3}{|c|}{ Diets } \\
\hline Ingredients & Basal & $\begin{array}{c}\text { Energetic } \\
\text { Ingredients }\end{array}$ & $\begin{array}{c}\text { Proteic } \\
\text { Ingredients }\end{array}$ \\
\hline Soybean meal & 57.50 & 34.50 & 40.24 \\
\hline Fishmeal & 5.50 & 3.30 & 3.85 \\
\hline Wheat bran & 2.00 & 1.20 & 1.40 \\
\hline Broken rice & 27.40 & 16.40 & 19.15 \\
\hline Soybean oil & 0.50 & 0.30 & 0.35 \\
\hline L- Lysine & 0.70 & 0.42 & 0.49 \\
\hline DL-Methionine & 0.45 & 0.27 & 0.32 \\
\hline Threonine & 0.40 & 0.24 & 0.28 \\
\hline $\begin{array}{l}\text { Bi-calcium } \\
\text { phosphate }\end{array}$ & 3.00 & 1.80 & 2.10 \\
\hline Limestone & 1.85 & 1.11 & 1.30 \\
\hline Sodium chloride & 0.10 & 0.05 & 0.06 \\
\hline Chromic oxide III & 0.10 & 0.10 & 0.10 \\
\hline
\end{tabular}

\begin{tabular}{|l|c|c|c|}
\hline $\begin{array}{l}\text { Ascorbic Acid - } \\
\text { Vitamin C }\end{array}$ & 0.08 & 0.06 & 0.07 \\
\hline Vitamin premix $^{1}$ & 0.10 & 0.06 & 0.07 \\
\hline Mineral premix $^{2}$ & 0.30 & 0.18 & 0.21 \\
\hline Antioxidant $^{3}$ & 0.02 & 0.1 & 0.1 \\
\hline $\begin{array}{l}\text { Tested Energetic } \\
\text { ingredients }\end{array}$ & - & $40.0 \%$ & - \\
\hline $\begin{array}{l}\text { Tested Proteic } \\
\text { ingredient }\end{array}$ & - & - & $30.0 \%$ \\
\hline Total (Total) & 100.00 & 100.00 & 100.00 \\
\hline
\end{tabular}

${ }^{1}$ Vitamin Premix, minimum level per kilogram: vitamin A, $16060 \mathrm{UI}$; vitamin $\mathrm{D}_{3}, 4510 \mathrm{UI}$; vitamin E, $250 \mathrm{UI}$; vitamin $\mathrm{K}, 30 \mathrm{mg}$; vitamin $\mathrm{B}_{1}$, $32 \mathrm{mg}$; vitamin $\mathrm{B}_{2}, 32 \mathrm{mg}$; calcium pantothenate, $80 \mathrm{mg}$; niacin, $170 \mathrm{mg}$; biotin, $10 \mathrm{mg}$; folic acid, $10 \mathrm{mg}$; vitamin $\mathrm{B}_{12}, 32 \mu \mathrm{g}$; vitamin $\mathrm{B}_{6}, 32 \mathrm{mg}$. ${ }^{2}$ Mineral premix, minimum level per kilogram: $\mathrm{Na}_{2} \mathrm{SO}_{3}, 0.7 \mathrm{mg}$; $\mathrm{MnO}, 50$ $\mathrm{mg} ; \mathrm{ZnO}, 150 \mathrm{mg} ; \mathrm{FeSO}_{4}, 150 \mathrm{mg} ; \mathrm{Cu} \mathrm{SO}_{4}, 20 \mathrm{mg} ; \mathrm{Co} \mathrm{SO}_{4}, 0,5 \mathrm{mg} ; \mathrm{I}_{2} \mathrm{Ca}$, $1 \mathrm{mg} .{ }^{3}$ Antioxidant: butylated hydroxytoluene.

Source: Research data.

The basal diet, a compound feed for omnivorous fish, was formulated to contain $31 \%$ of crude protein and $4.000 \mathrm{kcal}$ of gross energy $\mathrm{kg}^{-1}$. Apparent digestibility coefficients (ADC) were determined by the indirect method using chromium III oxide $(0.1 \%)$ as inert marker (BREMER NETO et al., 2005). Chemical composition of reference diet and ingredients tested are presented in Table 2.

Fish were allocated in a set of eight aquaria (250L) attached to a biofilter, constant aeration, digital heating system and containing $180 \mathrm{~L}$ polyethylene cages withholding 15 individuals $(75.0 \mathrm{~g} \pm 5 \mathrm{~g})$ each. Fish were kept in the cages for feeding and transfer to fecal collection system (eight aquaria with conical bottom and collecting vessel). Prior to the feces collection, experimental specimens were adapted to experimental conditions for five days.

Table 2 - Chemical composition of basal diet and tested ingredients*

\begin{tabular}{|l|c|c|c|}
\hline \multirow{2}{*}{ Ingredient } & \multicolumn{3}{|c|}{ Composition } \\
\cline { 2 - 4 } & $\begin{array}{c}\text { Dry matter } \\
(\%)\end{array}$ & $\begin{array}{c}\text { Crude } \\
\text { protein } \mathbf{( \% )}\end{array}$ & $\begin{array}{c}\text { Gross energy } \\
\left(\mathbf{k c a l ~ k g}^{-1}\right)\end{array}$ \\
\hline Basal Diet & 96.70 & 31.10 & 4.045 \\
\hline Broken rice & 90.08 & 8.43 & 3.761 \\
\hline Corn meal & 89.06 & 7.86 & 3.974 \\
\hline Wheat bran & 91.78 & 16.71 & 4.070 \\
\hline Soybean meal & 91.46 & 39.82 & 3.647 \\
\hline $\begin{array}{l}\text { Poultry by- } \\
\text { product meal }\end{array}$ & 95.37 & 66.80 & 5.037 \\
\hline Fishmeal & 89.26 & 51.34 & 3.813 \\
\hline
\end{tabular}

"Values obtained by analysis of two samples in duplicate.

Source: Research data.

Water quality was maintained by partial exchange and the aquariums daily cleaning 15 minutes after the last feeding. Parameters were monitored weekly through $\mathrm{pH}$ meter and digital oximeter, presenting the following: temperature 25.5 $\pm 0.8^{\circ} \mathrm{C} ; \mathrm{pH} 7.0 \pm 0.5$ and dissolved oxygen $6.2 \pm 0.6 \mathrm{mg} / \mathrm{L}$.

The feeding regime depended on feces collection procedures, at days without collection: fed four times (08AM, 11AM, 02PM and 05PM); and at collection days: fed twice in 
the morning (8AM and 11PM) and four times in the afternoon (02PM, 03PM, 04PM, 05PM and 06PM).

One hour after the last feeding procedure fish were transferred to conical aquaria until the next morning according to methodology proposed by Pezzato et al. (2002). Four samples of feces for each fish cage fed their respective test diets were performed, representing the repetitions. Feces collection were performed for eight days.

Fecal samples were dried at $55.0^{\circ} \mathrm{C}$, ground in a mill and stored at $-20.0^{\circ} \mathrm{C}$. Chemical composition of feedstuffs, experimental diets and feces were performed according to AOAC (2005) procedures. Chromic oxide content of diets and feces were determined according to Bremer Neto et al. (2005). Gross energy content was determined in an adiabatic calorimetric bomb.

The dietary nutrient and energy coefficient of apparent digestibility (ADC) were calculated through the chromium oxide concentration according to expressions proposed by Cho and Slinger (1979):

$$
A D C_{(n)}=100-\left[100\left(\frac{\% \mathbb{C}_{2} O_{3 r}}{\% \mathscr{C}_{2} O_{3 f}}\right) \times\left(\frac{\% N_{f}}{\% N_{r}}\right)\right]
$$

where:

$\mathrm{CDA}_{(\mathrm{n})}=$ Apparent digestibility coefficient of the diet ;

$\mathrm{Cr}_{2} \mathrm{O}_{3 \mathrm{r}}=\%$ Chromium oxide III content in the diet;

$\mathrm{Cr}_{2} \mathrm{O}_{3 \mathrm{f}}=\%$ Chromium oxide III content in the feces;

$\mathrm{N}_{\mathrm{r}}=$ Nutrient in the feed;

$\mathrm{N}_{\mathrm{f}}=$ Nutriente in the feces.
Apparent digestibility coefficient of nutrients and energy were calculated according the expressions described by Cho and Slinger (1979), as follows:

$$
A D C_{(n)}=\frac{A D C_{\mathbb{R}}-A D C_{R} \cdot x}{y}
$$

Where:

$\mathrm{ADC}_{(\mathrm{n})}=$ Ingredient Apparent Digestibility Coefficient $\mathrm{ADC}_{\mathrm{RT}}=$ Nutrient in Basal Diet Apparent Digestibility Coefficient $\mathrm{ADC}_{\mathrm{RR}}=$ Dietary Nutrient Apparent Digestibility Coefficient; $\mathrm{x}=$ Proportion of Basal diet;

$\mathrm{y}=$ Proportion of Experimental diet.

The average ADCs were subjected to analysis of variance (ANOVA) and Tukey test (5\%). All analyzes were performed using the GLM procedure using SAS.

\section{Results and Discussion}

Table 3 presents dry matter (DM), crude protein (CP) and gross energy (GE) ADC mean values and standard deviation, along with digestible values of energetic and proteic ingredients. Broken rice presented the highest ADC values of $\mathrm{DM}$, followed by corn meal and wheat bran $(\mathrm{P}<0.05)$. Crude protein $\mathrm{ADC}$ values did not differ significantly among the tested ingredients. Gross energy ADC values were superior in broken rice, followed by corn and wheat bran. Soybean meal and fishmeal presented the highest and lowest DM ADC values, respectively $(\mathrm{P}<0.05)$. $\mathrm{CP}$ of soybean meal presented better digestibility than the other ingredients $(\mathrm{P}>0.05)$.

Table 3 - Apparent digestibility coefficients (ADC) of nutrients, energy, and digestible values of protein and energy of energetic and proteic ingredients for goldfish.

\begin{tabular}{|l|c|c|c|c|c|}
\hline & \multicolumn{3}{|c|}{ ADC (\%) } & \multicolumn{2}{c|}{ Digestible Values } \\
\hline Ingredient & Dry matter & Crude protein & Gross energy & $\begin{array}{c}\text { Digestible Protein } \\
(\%)\end{array}$ & $\begin{array}{c}\text { Digestible energy } \\
\left(\mathrm{kcal} \mathrm{kg}^{-1}\right)\end{array}$ \\
\hline Broken rice & $97.19 \pm 2.66 \mathrm{a}$ & $81.80 \pm 4.87$ & $94.55 \pm 1.27 \mathrm{a}$ & 6.89 & $3,556.02$ \\
\hline Corn meal & $76.61 \pm 11.97 \mathrm{~b}$ & $90.77 \pm 12.44$ & $77.65 \pm 9.20 \mathrm{~b}$ & 7.13 & $3,085.81$ \\
\hline Wheat bran & $45.43 \pm 6.05 \mathrm{c}$ & $73.06 \pm 7.54$ & $48.83 \pm 2.12 \mathrm{c}$ & 12.21 & $1,987.38$ \\
\hline Soybean meal & $72.14 \pm 0.68 \mathrm{a}$ & $96.11 \pm 4.40 \mathrm{a}$ & $73.54 \pm 2.06$ & 38.27 & $2,682.00$ \\
\hline Poultry by-product meal & $61.77 \pm 5.39 \mathrm{ab}$ & $76.62 \pm 0.97 \mathrm{~b}$ & $69.50 \pm 3.89$ & 51.18 & $3,500.71$ \\
\hline Fishmeal & $47.48 \pm 11.52 \mathrm{~b}$ & $75.53 \pm 3.23 \mathrm{~b}$ & $60.65 \pm 17.30$ & 38.78 & $2,312.58$ \\
\hline
\end{tabular}

Mean values followed by different letters present significant differences (Tukey test $\mathrm{p}<0.05$ ). ADCs mean values are followed by standard deviation values.

Source: Research data.

The scarce knowledge about nutrient requirement and digestibility in feeds for ornamental fish has led to extrapolate the information available from farmed fish without considering the species-specific requirements; therefore, this practice could lead to affect negatively the growth performance, phenotype and physiology (VELASCO-SANTAMARÍA; CORREDORSANTAMARÍA, 2011). The lack of knowledge pointed out by these authors led to enormous difficulties to compare and discuss information about digestibility in goldfish. Thus, some of the comparisons carried out in this study were made to other omnivorous fish (principally Nile tilapia) or to other ornamental fish (as Siamese fighting fish) in which protein and energetic ingredients coincide with the ones studied herein as it could be viewed bellow.

In this study broken rice presented better digestibility of $\mathrm{DM}$ and GE, followed by corn meal and wheat bran, except for ADC values of CP. Some digestibility studies with Nile tilapia presented better CP ADC of corn meal when compared to wheat bran (FURUYA et al. 2001; PEZZATO et al. 2002). However, Pezzato et al. (2002) obtained similar ADC values of CP in corn meal (91.66\%) and wheat bran (91.13\%) for Nile tilapia, much higher digestibility values when compared to results for goldfish in this study.

Guimarães et al. (2008) obtained similar CP digestibility 
of broken rice (63.01\%) and wheat bran $(66.04 \%)$ and superior values of corn meal $(72.86 \%)$ in Nile tilapia compared to the present study. Nakagome (2009) also found higher ADC for $\mathrm{CP}$ in corn meal $(94.79 ; 87.00$ and $83.25 \%)$ when compared to broken rice $(74.45 ; 82.80$ and $83.75 \%)$ and wheat bran $(74.27$; 86.60 and $80.00 \%$ ) for Nile tilapia post-larvae.

Broken rice, corn meal and wheat meal $\mathrm{CP}$ ADC obtained for goldfish in this study were superior to results for Pseudoplatystoma coruscans (GONSALVES; CARNEIRO, 2003). Goldfish is an omnivorous species; therefore, its ability to use nutrients of plant origin feed is expected to be higher than the carnivorous $P$. coruscans. Nakagome (2009) also observed a better utilization of plant origin ingredient in tilapia when compared to carnivorous species. However, Zuanon et al. (2007) obtained similar digestibility values for carnivorous Betta splendens to omnivorous goldfish when studying corn meal and wheat bran, opposing affirmations that feeding habits limit digestibility of plant origin feeds.

Since the interaction among nutrients in feed ingredients may affect their digestibility, the highest ADC values of corn meal may be related to their amino acid composition that improves the proteic fraction usage of the test feed when that was combined to soybean meal. Additionally, this fact also may be related to the lower dietary protein levels when corn meal was tested in comparison to other energetic feeds.

DM and GE digestibility of wheat bran from this study when compared to ADC results obtained by Nile tilapia showed that goldfish is not so efficient to digest this ingredient, since its ADC values for GE and DM were lower the than values obtained by Gonsalves et al. (2004) (DM: 68.10\% and GE: $71.03 \%$ ) and Pezzato et al. (2002) (DM: 66.05\% and GE: $76.68 \%)$.

Despite wheat bran higher protein level, its high quantity of non starch poly-saccharides (NSPS) and fiber limits its inclusion in diets for monogastric animals (approximately 9.66\% DM basis, according to ROSTAGNO et al. 2005). Maes et al. (2002), state that wheat bran NSPS content is mainly composed by arabinoxylans (36.5\%), cellulose (11\%), lignin $(3-10 \%)$ and uronic acids (3-6\%). High levels of dietary fiber and NSPS hampers the nutrient digestion and absorption, affecting the carbohydrates, lipids and proteins digestibility. They also may increase amino acid and intestinal cells losses through secretion of endogen protein in the gut (BEDFORD; PARTRIDGE, 2001). Additionally, the wheat endosperm cellular physical structural arrangement may prevent action of digestive enzymes on nutrients contained in this grain (BEDFORD, 2000).

Furuya et al. (2001) results presented lower digestibility of wheat bran CP compared to corn for Nile tilapia, appointing fiber and NSPS as factors affecting intestinal transit. Nakagome (2009) recommended to avoid wheat bran in feeds for Nile tilapia under $3.76 \mathrm{~g}$ due its high levels of fiber and NSPS. In the present study, this ingredient also presented lower digestibility, requiring caution on its utilization on feeds for goldfish, observing principally the amount of fiber on the diet in order to avoid compromising the reasonable digestibility.

Several digestibility studies of corn and broken rice for Nile tilapia presented some variation when compared to ADC values obtained for goldfish where Guimarães et al. (2008) observed digestibility for corn $82.21 \%$ and $67.37 \%$, DM and GE, respectively. In the same study the authors affirmed that broken rice ADC were: 95.34\% (GE) and 96.45 (DM). Similar results were obtained by Nakagome (2009) for Nile tilapia.

Zuanon et al. (2007) determined DM and CP digestibility feed ingredients for betta fish, and their results showed that this species is more efficient to digest wheat bran $(61.06 \%$ DM; $58.17 \%$ CP) when compared to goldfish. However, this efficiency does not apply to corn meal since ADC values of betta for this feed $(63.88 \% \mathrm{DM} ; 77.61 \% \mathrm{CP})$ were lower than results from the present study.

Analyzing digestibility of feed ingredients by the kinguios, Bahiense (2017) found that rice crude protein (81.14) and energy (100.00) were highly digestible when compared with wheat and sorghum. This author also affirmed that the rice protein digestibility (89.40) presented high coefficient, however the protein digestibility of wheat presented greater values (98.83). Bahiense (2017) also stated that the elevated values of rice dry matter digestibility are similar to starch digestible values. This author tested different ingredients in comparison to the present study, however, it is possible to affirm that rice digestibility presented higher digestible coefficients in both studies.

In this study soybean meal present higher CP ADC, followed by poultry by-product meal and fishmeal. Soybean meal also presented higher digestibility of $\mathrm{CP}$ and GE compared to animal origin protein feeds.

Nile tilapia digestibility studies also obtain better CP digestibility of soybean meal when compared to fishmeal (84.95\%-88,60\%) (FURUYA et al., 2001; GUIMARÃES et al., 2008a) and poultry by-product meal (GUIMARÃES, et al., 2008a). Pezzato et al. (2002), also studying the same species, observed better DM and CP digestibility in soybean meal (71.04 and $91.56 \%$, respectively) and poultry by-product meal (73.87 and 87.24\%) when compared to fishmeal analysis (57.46 and $78.55 \%$ ). The present study presented similar results. However, Degani et al. (1997), affirmed that carp (Cyprinus carpio) exhibited superior CP ADC for fishmeal $(83,83 \%)$, followed by soybean meal $(69.83 \%)$ and poultry by-product meal $(47.15 \%)$. These last results confront the outcomes of the present research.

Nakagome (2009) studying three sizes of tilapia postlarvae also obtained superior ADC values for soybean meal CP and DM compared to poultry by-product meal and fishmeal. Low values of gross energy and ADC led to diminished apparent digestible energy (ADE, $\mathrm{kcal} \mathrm{kg}^{-1}$ ) in soybean meal and fishmeal when confronted to Pezzato et al. (2002) (3064 and $3138 \mathrm{kcal} \mathrm{kg}^{-1}$, respectively) and Nakagome (2009) (3128; 3214 and 3.322 for soybean meal and 3180; 3442 and 
$3594 \mathrm{kcal} \mathrm{kg}^{-1}$ for fishmeal, respectively). However, in this study ADE values for poultry by-product meal were similar to results obtained by Pezzato et al. (2002) (3.543 kcal kg-1) and by Nakagome (2009) (3485; 3662 and $\left.3705 \mathrm{kcal} \mathrm{kg}^{-1}\right)$.

When digestibility values of Brazilian fishmeal and soybean meal were compared in the study carried out by Bahiense (2017), the results showed better AD to the plantorigin ingredient. According this author, these results could be explained by goldfish natural fish habits: omnivorous tending to herbivore. The goldfish feeding habit may also explain the highest ADC values obtained to soybean meal in the present study.

Fishmeal is a traditional ingredient in fish diets, often credited as a major component of feeds especially for carnivorous species with higher protein requirements. In contrast, as the results obtained in this study, there is better nutrient and energy utilization from other sources of protein, when compared to fishmeal. Perhaps the main reason for this to occur is the wide variation in the quality of this ingredient. For Furuya et al. (2001) the lowest ADC of protein and amino acids observed for fishmeal in relation to the soybean meal, is principally related to the quality of the first, as the content of bones and connective tissues, in addition to processing, such as heat and solvents used to obtain it. Additionally, fishmeal made in Brazil is composed by fish residues and has limited quantity and quality (LIMA et al., 2014), what is the decisive factor to its nutrient availability.

Furthermore, the consensus is that plant origin feeds are less subject to variation in their chemical composition, due the stability of their biological tissues in cultivation or even the processing standardization compared to animal origin feeds. For instance, given the growing demand for fishmeal use in feeds, and consequently, its high cost, it exhibits | significant variation on its chemical composition and quality, which directly influences its digestibility. Apparently, in general, poultry meal presents better stability on its quality.

\section{Conclusion}

The studied energetic ingredients can be used as energy sources in diets for this species, especially broken rice, followed by corn meal. However, wheat bran inclusion in feeds for goldfish must be judiciously evaluated to avoid poor digestibility of nutrients and energy in balanced diets. Soybean meal is a highly digestible protein source for the species, even in comparison with poultry by-product meal and fishmeal.

\section{References}

AOAC - Association of Official Analytical Chemists. Oficcial methods of analysis of AOAC International. $18^{\text {th }}$ Edition. Gaithersburg: AOAC, 2005.

BAHIENSE, R.N. Digestibilidade de alimentos proteicos e energéticos para kinguios (Carassius auratus). Belo Horizonte: UFMG, 2017.

BANDYOPADHYAY, P.; SWAIN, S.K.; MISHRA, S. Growth and dietary utilisation in goldfish (Carassius auratus Linn.) fed diets formulated with various local agro-produces. Bioresour. technol., v.96, p.731-740, 2005. doi: 10.1016/j.biortech.2004.06.018.

BREMER NETO, H.; GRANER, C.A.F.; PEZZATO, L.E. The spectrophotometric method on the routine of 1,5-diphenylcarbazide was adjusted on chromium determination in feces, after its utilization as a biological marker as chromium (III) oxide. Cienc. Rural, v.25, p.691-697, 2005. doi: 10.1590/ S0103-84782005000300033.

BEDFORD, M.R. Exogenous enzymes in monogastric nutrition: their current value and future benefits. Anim. Feed Sci. Tech., v.86, p.1-13, 2000. doi: 10.1016/S0377-8401(00)00155-3.

BEDFORD, M.R.; PARTRIDGE, G.G. Enzymes in Farm Animal Nutrition. Wiltshire: CABI Publishing, 2001.

CHO, C.Y.; SLINGER, S.J. Apparent digestibility measurements in feedstuffs for rainbow trout. In: HALVER, J.E. \& TIEWS. Finfish nutrition and fishfeed technology, Berlin: Proceedings of the World Symposium of Finfish Nutrition and Fishfeed Technology, v. 2, p.239-247, 1979.

DEGANI, G.; REVACH, A. Apparent digestibility coefficient of protein sources for carp, Cyprinus carpio L. Aquac. Res., v.28, p.23-28, 1997. doi: 10.1046/j.1365-2109.1997.00825.x.

FURUYA, W.M. et al. Coeficientes de Digestibilidade e Valores de Aminoácidos Digestíveis de Alguns Ingredientes para Tilápia do Nilo (Oreochromis niloticus). Rev. Bras. Zootec., v.30, n.4, p.1143-1149, 2001. doi: 10.1590/S1516-35982001000500002.

GONSALVES, E.G.; CARNEIRO, D.J. Coeficientes de digestibilidade aparente da proteína e energia de alguns ingredientes utilizados em dietas para o pintado (Pseudoplatystoma coruscans). Rev. Bras. Zoot., v.32, n.4, p.779-786, 2003. doi: 10.1590/S1516-35982003000400001.

GUIMARÃES, I.G. et al. Nutrient digestibility of cereal grain products and by-products in extruded diets for Nile tilapia. $J$. World Aquacult. Soc., v.39, p.781-789, 2008. doi: org/10.1111/ j.1749-7345.2008.00214.x.

GUIMARÃES, I.G.; BARROS, M.M.; PEZZATO, L.E. Amino acid avaliabilty and protein digestibility of several protein sources for Nile tilapia, Oreochromis niloticus. Aquac. Nut., v.14, p.396404, 2008a. doi: 10.1111/j.1365-2095.2007.00540.x.

LIMA, R.L. et al. Redução do fósforo pela peneiragem da farinha de resíduos de peixes. Cienc. Rural, v.44, n.10, p.1841-1844, 2014. doi: 10.1590/0103-8478cr20130935.

MAES, C.; VANGENEUGDEN, B.; DELCOUR, J.A. Relative activity of two endoxylanases towards water-unextractable arabinoxylans in wheat bran. J. Cereal Sci., v.39, p.181-186, 2004. doi: $10.1016 /$ j.jcs.2003.08.001.

NAKAGOME, F.K. Digestibilidade aparente de ingredientes por alevinos de tilápia do Nilo (Oreochromis niloticus). 2009. 58f. Dissertação (Mestrado) - Curso de Pós-graduação em Zootecnia, Universidade Estadual Paulista.

PAULET, T.G. The effect of diet type and feeding rate on growth, morphological development and behaviour of larval and juvenile goldfish Carassius auratus (L.). 2003. 111f. Thesis (Master of Science). Rhodes University.

PEZZATO, L.E. et al. Digestibilidade aparente de ingredientes pela tilápia do Nilo (Oreochromis niloticus). Rev. Bras. Zoot., v.31, n.4, p.1595-1604, 2002. doi: 10.1590/S151635982002000700001 .

ROSTAGNO, H.S. et al. Tabelas brasileiras para suínos e aves: Composição de alimentos e exigências nutricionais. $2^{\mathrm{a}}$ Edição. Viçosa: UFV, 2005. 
TAMARU, C.S; AKO, H. Using comercial feeds for the culture of freshwater ornamental fishes in Hawai'i. In: Tamaru, C. et al. Spawning and maturation of aquatic species, USA: UJNR Technical Report No.28, v.1, p.109-120, 1999.

TLUSTY, M.F. et al. Opportunities for public aquariums to increase the sustainability of the aquatic animal trade. Zoo Biol., v.32, p.1-12, 2013.

VELASCO-SANTAMARÍA, Y.; CORREDOR-SANTAMARÍA,
W. Nutritional requirements of freshwater ornamental fish: a review. Rev. MVZ Cordoba, v.16, n.2, p.2458-2469, 2011.

ZUANON, J.A.S. et al. Níveis de proteína bruta em dietas para alevinos de acará-bandeira. Rev. Bras. Zoot., v.35, n.5, p.18931896, 2006. doi: 10.1590/S1516-35982006000700003.

ZUANON, J.A.S. et al. Digestibilidade de alimentos protéicos e energéticos para fêmeas de beta. Rev. Bras. Zoot., v.36, n.4 (supl.), p.987-991, 2007. doi: 10.1590/S1516-35982007000500001. 